\title{
Impact of Field and Laboratory Environmental Conditions on the Diversity of Wood-Decay Fungi in the Forests of Northwest Arkansas
}

\author{
Nawaf I. Alshammari ${ }^{1}$ (D), Vajid N. Veettil ${ }^{1}$ (D) Abdel Moneim E. Sulieman $^{1 *}$ (D) and \\ S.L. Stephenson ${ }^{2}$
}

${ }^{1}$ Department of Biology, Faculty of Sciences, University of Hail, Hail, Saudi Arabia.

${ }^{2}$ Department of Biological Sciences, University of Arkansas, Fayetteville, Arkansas USA.

\begin{abstract}
Environmental factors such as temperature and humidity directly affect the growth and fruit bodies of fungi. We studied the diversity of wood decaying fungal species, which have grown on same substrate in forest as well as laboratory environment. Ten specimens of fruit body of wood-decaying fungi and 24 random pieces of coarse wooden debris were collected from the forest of northwest Arkansas. The samples of coarse woody debris were incubated in laboratory-growth chambers for two months to promote the fungal growth. Fourty-two different species of wood-decay fungal isolates were recovered and identified by internal transcribed spacer (ITS) region sequencing. The isolates from the forest belonged to twenty-two different taxa whereas twenty taxonomic groups were reported from the growth compartments. Remarkably, data observed from two sets did not shared any taxon. These results indicated that environmental growth conditions play crucial role on fungal diversity even if grown on same substrates.
\end{abstract}

Keywords: Fruit body of fungi, decaying wood, environmental growth conditions, internal transcribed spacer (ITS), fungal biodiversity

\footnotetext{
*Correspondence: abuelhadi@hotmail.com

(Received: May 11, 2020; accepted: July 17, 2020)

Citation: Alshammari NI, Veettil VN, Sulieman AME, Stephenson SL. Impact of Field and Laboratory Environmental Conditions on the Diversity of Wood-Decay Fungi in the Forests of Northwest Arkansas. J Pure Appl Microbiol. 2020;14(3):1801-1808. doi: 10.22207/JPAM.14.3.18

(C) The Author(s) 2020. Open Access. This article is distributed under the terms of the Creative Commons Attribution 4.0 International License which permits unrestricted use, sharing, distribution, and reproduction in any medium, provided you give appropriate credit to the original author(s) and the source, provide a link to the Creative Commons license, and indicate if changes were made.
} 


\section{INTRODUCTION}

Wood-saprophytic fungi play significant role within the functioning of forest ecosystems (Lonsdale et al., 2008). They provide a sustainable habitat for several other species, are directly involved in nutrient cycling and through the removal of coarse woody debris literally set the stage for the restoration of forests around the world. Because of their importance, microbiologist, mycologist, forest ecologists and pathologists carefully observe these organisms (Lonsdale et al., 2008).

In a forest ecosystem, coarse woody debris facilitates seedling survival by its capacity for moisture retention, serves as barrier for soil-borne pathogens and represents a major source for the nutrients required for plant growth and development. These factors facilitate the occurrence of mycorrhizal fungi (Miller, 1995). The species richness of wood-decay fungi increases with the number of woody substrates, which means that a positive relationship exists between the latter and the numbers of both species and fruit bodies in a forest (Simila et al., 2006). The process of wood decay involving different substrates is fundamental for the formation of different ecological niches of the species involved, which show wide variety of potential decay pathways based on variety inherent in the substrates available (Odling-Smee et al., 2003).

The overall object of the present study was to provide a more complete understanding of fungal ecology and diversity in the forests of northwest Arkansas. It was carried out in Devil's Den State Park area $\left(36^{\circ} 46^{\prime} 28^{\prime \prime} N, 9^{\circ} 14^{\prime} 30^{\prime \prime}\right.$ W), which is of 1011 ha neighboring the border Arkansas, Oklahoma border. According to the report of Washington County Historical Society, what was to become the state park was established by the Civilian Conservation Corps in the year of 1930. The major feature of the park is that it conserve the principal sandstone crevice region in the United States of America. The forest representing in comparable composition to those found throughout much of northwest Arkansas, with various species of oak and hickory consistently the dominant trees present. However, it also holds a diverse population of species like red maple (Acer saccharum Marshall and Acer rubrum
L.) that are characteristic only of the relatively more mesic sites (Stephenson et al., 2007).

The most significant factors affecting fungal propagation are moisture, temperature and nutrient availability (Vacher et al., 2010). In addition, the range of available substrates also is important, since the assemblage of fungi present often displays significant variation among different habitats that differ with respect to forest composition (Djurle et al., 1996). Studies have shown that saprotrophic fungi grow well at humidity levels around $28 \%$ to $30 \%$ (Jacobson, 2015), and 20\% humidity provides a margin of safety against fungal decay (Griffin, 1977). However, environment conditions can vary considerably over time with changes in the weather. In the laboratory, relatively constant and uniform conditions can be maintained, and the question might be asked if this difference results in the appearance of species of fungi that do not necessarily form fruit bodies in the field. The study reported herein was designed to determine to what extent this is indeed the case.

\section{MATERIALS AND METHODS}

The study area in Devil's Den State Park was visited during November 2018. A total of 30 different saprophytic fungal fruit bodies were collected according to Cannon and Sutton (2004). The sporocarp were then photographed in the study site, collected aseptically with knife, wrapped in multiple slits of bag, and stored into the lab. Additionally, 24 small bits of coarse woody fragments with approximately $>10 \mathrm{~cm}$ diameter collected randomly from the study area along with 10 specimens of fungi along with their associated coarse woody debris. All of the samples of coarse woody debris were incubated in polypropylene incubation containers (each approximately $30 \times 12 \times 6 \mathrm{~cm}$ ) (Alshammari et al., 2018). In these chambers, the environment factors were controlled. Temperature range was maintained between $25-30^{\circ} \mathrm{C}$ and water was added whenever a particular incubation chamber showed any sign of low moisture level (Figs. 1 and 2). The chambers were observed over a period of two months. Upon observation of sporocarp they were recorded as image, removed from growth media and desiccated at $42-55^{\circ} \mathrm{C}$ temperature range, on 
a desiccator for about 48 hours. Primary features such as color, shape and size were recorded prior to drying the fruit bodies. In addition, very small fruit bodies were preserved in the refrigerator for morphological identification of the specimens, which was accomplished with the use of such publications as Gilbertson and Ryvarden (1986, 1987), Bessette et al. (1997), Barron (1999), Binion et al (2008), Sotome et al. (2013) and Elliott and Stephenson (2018).

\section{DNA Extraction, PCR and Sequencing}

Total genomic DNA from dried fungal tissue extracted by Wizard ${ }^{\circledR}$ genomic purification kit (Promega, USA). The ITS region of rDNA was targeted for PCR amplification with the primers ITS1 (5'-TCCGTAGGTGAACCTGCGG-3') and ITS4 (5'-TCCTCCGCTTATTGATATGC-3') (White, 1992). PCR reactions were carried out in gradient thermal cycler set at $95^{\circ} \mathrm{C}$ (initial denaturation five minutes), followed by 35 cycles consist of denaturation $\left(95^{\circ} \mathrm{C}\right.$ for $\left.45 \mathrm{sec}\right)$ primer annealing $\left(50^{\circ} \mathrm{C}\right.$ for $\left.45 \mathrm{sec}\right)$, and extension $\left(72^{\circ} \mathrm{C}\right.$ for 1.5 min), and a final extension at $72^{\circ} \mathrm{C}$ for $10 \mathrm{~min}$. The PCR product were further confirmed by electrophoresis. Sanger sequencing GeneWiz (South Plainfield, New Jersey) sequenced the amplicons. The result nucleotide sequences were identified blastn search tool. Moreover, taxa were considered to be identified to the level of with a identity match $\sim 97 \%$ or greater sequence identity, whereas those with a sequence identity less than $95 \%$ were considered were to be identified to the level of genus. The nucleotide sequences was deposited to the GenBank. The author of each fungal taxon was determine using information available on the Index Fungorum web site.

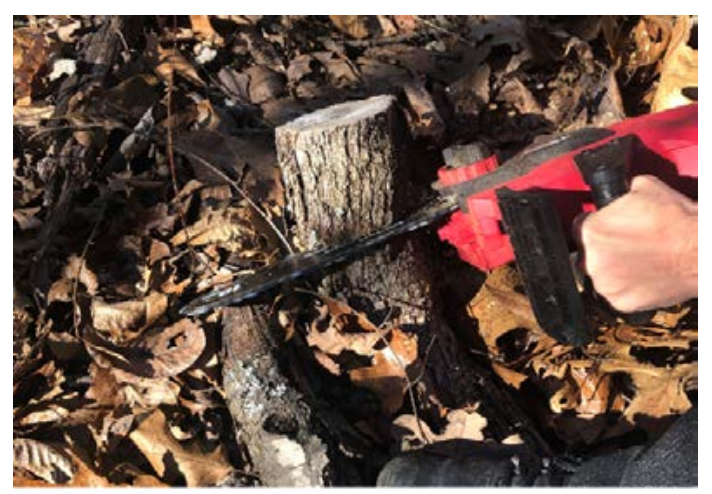

Fig. 1. Representation pieces of coarse woody debris of the same species collected from the field.
Phylogenetic analysis was carried out using the ITS gene sequences of each isolate and analyzed in Bio Edit 3.6a2 software using the Neighbor-Joining/UPGMA method Hall (1999).

\section{RESULTS}

A total of 48 specimens of macro fungi were sequenced. Out of the 48 , sequences from six specimens were of poor quality and thus not included in the analysis. Out of good quality sequences, 42 different taxa (Tables 1 and 2) were identified. Twenty-two fungal sp were confirmed as field set, while 20 fungal sp were confirmed from the growth chambers. Unexpectedly, the field and incubation chamber data did not share any species. The species identified belonged to 28 different families, with 15 and 13 different families represented among field and incubation chambers data respectively, with members of the Mycenaceae, Polyporaceae, Hymenochaetaceae, Xylariaceae, Pluteaceae, and Marasmiaceae as the abundant species (Table 3).

Phylogenetic analysis by neighbor joining method showed four different clusters of fungal species recovered from the samples of coarse woody debris (Fig. 4).

\section{DISCUSSION}

Numerous research have been conducted in several parts of the globe to investigate the species of fungi associated with coarse woody debris. Many of them have investigated the fungi in various places flora in the United States. For example, Leiniger (1977) worked in Louisiana,

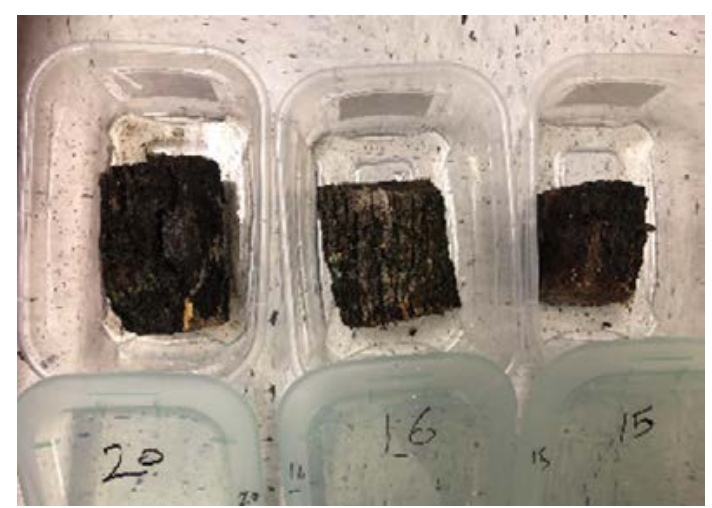

Fig. 2. Course woody debris placed in the incubation chambers. 
Bessette (1997) and Binion et al (2008) considered the fungi isolation in the eastern part of the country. Similar studies are available for other countries such as Ethiopia and India (Alemu 2013, Lyngdoh and Dkhar 2014, Bhutia 2016).

A preliminary study on the species of fungi in northwest Arkansas was carried out by one of our teams in 2018 (Alshammari et al., 2018). In this study, 77 different taxa of fungi were represented by field samples, whereas 34 species were observed from fungal growth chambers.

Based on this preliminary study, we have planned to further investigate the variation of the fungal taxa in Devil's Den State park, which is a part of the largest forest area of Arkansas i.e. Ozark National forest. A study available in the literature showed there are 51 species of flora available in the State park (Jeffries et al., 1987). This widespread vegetation must play important roles to grow various macrofungal species, which will enable us to study the detailed biodiversity of fungal species of the forest area.

In the present study, the fruit bodies of the fungi were collected in the month of November, which is not the favorable period of the year for most fungi. The climate of northwest Arkansas in November is moderately cold (average temperatures range from 2 to $15^{\circ} \mathrm{C}$ ), with a mean level of humidity of $70 \%$ and relatively little precipitation (www.accuweather.com). These conditions were conducive to collect in the field but certainly did not allow the full biodiversity of the mycoflora to be captured. However, the wood-decay fungi include many species that are perennial and thus present well outside the usual field season.

To minimize this variation in the result, fungal species were collected randomly or from the same substrates (logs or branches, etc), parts of which were incubated in the laboratory. Moreover, the samples were collected in the same or short period of time interval (two months), which was expected to overcome the weather variation to minimize fungal diversity. In the earlier study mentioned above, the sets of data obtained for field collections and the incubation chamber shared no species in common. The results of the present study followed this same general pattern except the fact that two species belonged to the genus Gymnopus were recorded from two different substrates, with one collection from the field and another from the incubation chambers (Alshammari et al., 2019).

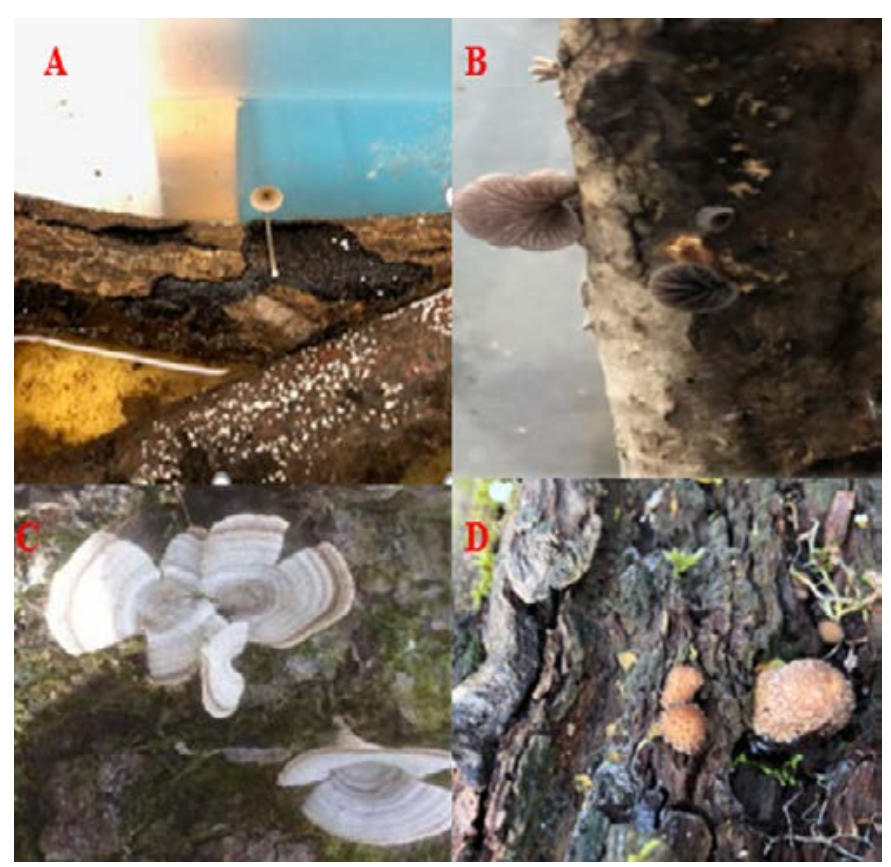

Fig. 3. Different species of wood-decay fungi collected from the incubation chambers and the field; A. Pluteu romellii, B. Resupinatus alboniger, C. Lenzites betulinus and D. Lycoperdon pyriforme respectively. 
Presumably, there were appreciable differences in the environmental conditions that exist in the field of study i.e. forest area as compared to the incubation chamber. These would include differences in light, moisture level, temperature, and oxygen content. For example, moisture levels can fluctuate greatly in a piece of coarse woody debris in the field, but in an

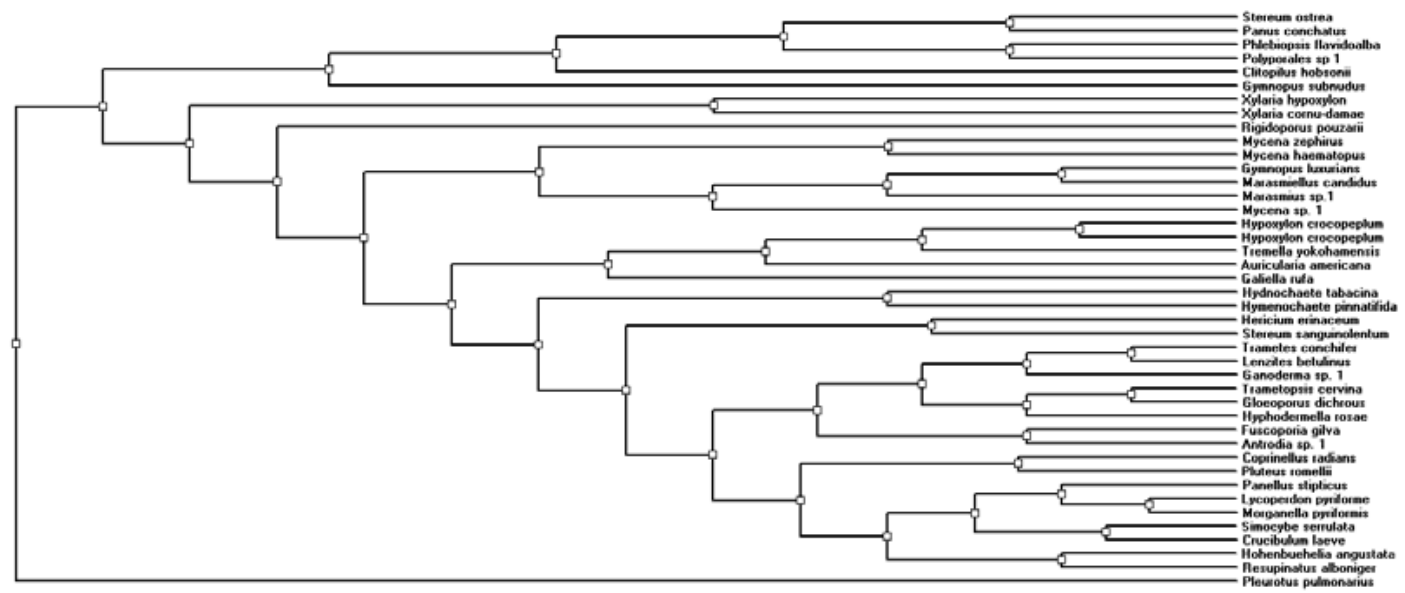

Fig. 4.

Table 1. Species of fungi recovered from different substrates from the field and the incubation chambers

\begin{tabular}{|c|c|c|c|}
\hline Field sp. & SGB & Incubation chambers sp. & SGB \\
\hline Fuscoporia gilva (Schwein.) & MN781978.1 & Galiella rufa (Schwein.) & MN826132.1 \\
\hline T. Wagner \& M.. Fisch & & Nannf. \& Korf & \\
\hline Ganoderma sp. 1 & MN749648.1 & Mycena zephirus (Fr.) P. Kumm & MN781987.1 \\
\hline Gloeoporus dichrous (Fr.) Bres. & MN749625.1 & Gymnopus luxurians (Peck) Murrill & MN860558.1 \\
\hline $\begin{array}{l}\text { Gymnopus subnudus } \\
\text { (Ellis ex Peck) Halling }\end{array}$ & МT027360.1 & Marasmiellus candidus (Fr.) Singer & MN977325.1 \\
\hline $\begin{array}{l}\text { Hericium erinaceus } \\
\text { (Bull.) Pers. }\end{array}$ & MN752252.1 & Marasmius sp.1 & MN872842.1 \\
\hline $\begin{array}{l}\text { Hohenbuehelia angustata } \\
\text { (Berk.) Singer }\end{array}$ & MN808821.1 & $\begin{array}{l}\text { Mycena haematopus (Pers.) } \\
\text { P. Kumm. }\end{array}$ & MN749929.1 \\
\hline $\begin{array}{l}\text { Hydnochaete tabacina } \\
\text { (Berk. \& M.A. Curtis ex Fr.) } \\
\text { Ryvarden }\end{array}$ & MN749624.1 & Mycena sp. 1 & MN781994.1 \\
\hline $\begin{array}{l}\text { Hymenochaete pinnatifida } \\
\text { Burt }\end{array}$ & MN749653.1 & $\begin{array}{l}\text { Pluteu romellii (Britzelm.) } \\
\text { Sacc. }\end{array}$ & MN752313.1 \\
\hline $\begin{array}{l}\text { Hyphodermella rosae (Bres.) } \\
\text { Nakasone }\end{array}$ & MN749631.1 & $\begin{array}{l}\text { Clitopilus hobsonii (Berk.) } \\
\text { P.D. Orton }\end{array}$ & МT032481.1 \\
\hline $\begin{array}{l}\text { Hypoxylon crocopeplum Berk. } \\
\text { \& M.A. Curtis }\end{array}$ & MN964272.1 & $\begin{array}{l}\text { Tremella yokohamensis (Alshahni, } \\
\text { Satoh \& Makimura) Yurkov }\end{array}$ & MN752643.1 \\
\hline Lenzites betulinus (L.) Fr. & MN749633.1 & Panus conchatus (Bull.) Fr. & МT032480.1 \\
\hline Antrodia sp. & MN749970.1 & Resupinatus alboniger (Pat.) Singer & MN752401.1 \\
\hline $\begin{array}{l}\text { Auricularia Americana Parmasto } \\
\text { \& I. Parmasto }\end{array}$ & MN752647.1 & $\begin{array}{l}\text { Stereum sanguinolentum } \\
\text { (Alb. \& Schwein.) Fr }\end{array}$ & MN864252.1 \\
\hline $\begin{array}{l}\text { Coprinellus radians (Fr.) Vilgalys, } \\
\text { Hopple \& Jacq. Johnson }\end{array}$ & MN753980.1 & $\begin{array}{l}\text { Xylaria cornu-damae (Schwein.) } \\
\text { Berk. }\end{array}$ & МT027514.1 \\
\hline Crucibulum leave (Huds.) Kambly & MN749576.1 & $* * *$ & $* * *$ \\
\hline
\end{tabular}


Table 2. Species of fungi recovered from the same substrates from the field and the incubation chambers

\begin{tabular}{|c|c|c|c|}
\hline Field & SGB & Incubation chamber & SGB \\
\hline Pleurotus pulmonarius (Fr.) Quel & MN808603.1 & $\begin{array}{l}\text { Phlebia tremellosa } \\
\text { (Schrad.) Nakasone \& } \\
\text { Burds. }\end{array}$ & KJ668481.1 \\
\hline Panellus stipticus (Bull.) P. Karst. & MN749586.1 & Xylaria sp. 1 & Мт028182.1 \\
\hline Lycoperdon pyriforme Schaeff. & MF161171.1 & $\begin{array}{l}\text { Simocybe serrulata } \\
\text { (Murrill) Singer }\end{array}$ & MN809120.1 \\
\hline $\begin{array}{l}\text { Hypoxylon crocopeplum Berk. \& } \\
\text { M.A. Curtis }\end{array}$ & MN964272.1 & Rigidoporus sp. 1 & MG845229.1 \\
\hline $\begin{array}{l}\text { Stereum ostrea (Blume \& T. } \\
\text { Nees) Fr. }\end{array}$ & MN749635.1 & $\begin{array}{l}\text { Trametopsis cervina } \\
\text { (Schwein.) Tomsovsky }\end{array}$ & MN749931.1 \\
\hline $\begin{array}{l}\text { Trametes conchifer (Schwein.) } \\
\text { Pilat }\end{array}$ & MN749629.1 & Polyporales sp. 1 & MN809134.1 \\
\hline $\begin{array}{l}\text { Morganella subincarnata (Peck) } \\
\text { Kreisel \& Dring }\end{array}$ & MN964264.1 & $* * *$ & $* * *$ \\
\hline
\end{tabular}

Table 3. Common families of wood-decay fungi collected in the present study from both the field and incubation chambers

\begin{tabular}{ll}
\hline Field Families & $\begin{array}{l}\text { Incubation chambers } \\
\text { Families }\end{array}$
\end{tabular}

\begin{tabular}{|c|c|c|c|}
\hline 1. & Agaricaceae & 1. & Polyporaceae \\
\hline 2. & Auriculaceae & 2. & Entolomataceae \\
\hline 3. & Ganodermataceae & 3. & Inocybaceae \\
\hline 4. & Hericiaceae & 4. & Marasmiaceae \\
\hline 5. & Hymenochaetaceae & 5. & Meripilaceae \\
\hline 6. & Marasmiaceae & 6. & Mycenaceae \\
\hline 7. & Meruliaceae & 7. & Panaceae \\
\hline 8. & Mycenaceae & 8. & Phanerochaetaceae \\
\hline 9. & Nidulariaceae & 9. & Pleurotaceae \\
\hline 10. & Phanerochaetaceae & 10. & Polyporaceae \\
\hline 11. & Pleurotaceae & 11. & Sarcosomataceae \\
\hline 12. & Polyporaceae & 12. & Stereaceae \\
\hline 13. & Psathyrellaceae & 13. & Xylariaceae \\
\hline 14 & Stereaceae & & \\
\hline 15 & Xylariaceae & & \\
\hline
\end{tabular}

incubation chamber, moisture levels are relatively constant and probably near saturation in many instances, since the bottom of the chamber had standing water present invariably. Light and temperature were also controlled in the incubation chambers but were different than open forest, where daily and seasonal variation of temperature must be a natural phenomenon in two months. These differences in growth conditions are known to play essential as well as significant role in the growth of fungi (Ali et al., 2017).
The phylogenetic relationships among the fungi collected in the present study clearly indicates a high level of taxonomic diversity, which suggests that representatives of numerous groups have evolved to exploit the various niches associated with the decomposition of coarse woody debris (Fig. 4). Therefore, this study demonstrates that the growth factors also monitor the quality and variation in the fungal species as described by previous studies (Kazemian, 2019, Ligne, 2019). The reason behind these enormous variation in fungal species is clear i.e., various combination of temperatures, oxygen contents and moisture levels are optimum for the germination of different fungal spores and probably also responsible for the formation of fruit bodies. It is difficult to know what factors inhibit or encourage the growth of specific species of fungi, but the fact that these fungi do respond to a complex of factor cannot be disputed, based on the data obtained in this study.

One of the authors of this study has personally observed, some species recorded only from incubation chambers have been observed to form fruit bodies in the field, and probably all the fungal species in this set (grown inside the chamber) are likely to form fruit bodies in the forest environment under certain environmental conditions (Unpublished data). One limitation in drawing conclusions that are more comprehensive is that the incubation chamber method of assessing fungal diversity has not been widely used. In fact, we are not aware of any studies other 
than the previous study by Alshammari (2019). There is little doubt that additional investigations need to be carried out.

This primary contribution of the present study is that it added to what is known about the biodiversity of fungi, specifically wood-decay fungi, in northwest Arkansas. Unfortunately, this region of the United States is seriously understudied for all groups of fungi. This study also provided additional evidence of the usefulness of incubation chambers for characterizing the assemblage of wood-decay fungi at a particular locality.

\section{ACKNOWLEDGMENTS}

Authors would like to thank University of Hail for their assistance. Also, the authors would like to thank the University of Arkansas due to their support in part through the Slime Mold Project account.

\section{CONFLICT OF INTEREST} conflict of interest.

The authors declare that there is no

\section{AUTHORS' CONTRIBUTION}

All authors designed the experiments. $\mathrm{N}$. IAIS, VNV, AM, ES and S, SL performed the experiments. NIAIS, VNV and AM, ES analyzed the data. Stephenson, SL and NIAIS and VNV wrote the manuscript. All authors read and approved the manuscript.

\section{FUNDING}

None.

\section{ETHICS STATEMENT}

This article does not contain any studies with human participants or animals performed by any of the authors.

\section{DATA AVAILABILITY}

The datasets generated and/or analyzed during the current study are available in the GenBank database repository, Accession No: MN826132.1, MN781987.1, MN860558.1, MN977325.1, MN872842.1, MN749929.1, MN781994.1, MN752313.1, MT032481.1, MN752643.1, MT032480.1, MN752401.1, MN864252.1, MT027514.1, KX065956.1,
MT028182.1, MN809120.1, MG845229.1, MN749931.1, MN809134.1

\section{REFERENCES}

1. Alemu F. Assessment of wild mushrooms and wooddecay fungi in Dilla University, Main Campus, Ethiopia. Int J Adv Res. 2013;1:458-467.

2. Alshammari N, Stephenson S. A preliminary study of wood-decay fungi in forests of northwest Arkansas. Current Research in Environmental \& Applied Mycology. 2018;8(5):556-563. doi: 10.5943/cream/8/5/4

3. Barron G. Mushrooms of Northeast North America. Lone Pine Publishing, Vancouver, British Columbia. 1999.

4. Bessette AE, Bessette AR, Fischer DW. Mushrooms of Northeastern North America. Syracuse University Press, Syracuse, New York. 1997.

5. Bessette A, Miller Jr OK, Miller HH. Mushrooms of North America in color: A field guide companion to seldom-illustrated fungi. Syracuse University Press, New York. 1995.

6. Bhutia LP. A preliminary survey on diversity of wood decay fungi from East Sikkim. Journal of Mycopathological Research. 2016;54:255-261.

7. Binion DE, Stephenson SL, Roody WC, Burdsall HH. Macrofungi Associated with Oaks of Eastern North America. West Virginia University Press, Morgantown, West Virginia. 2008.

8. Djurle A, Ekbom B, Yuen JE. The relationship of leaf wetness duration and disease progress of glume blotch, caused by Stagonospora nodorum, in winter wheat to standard weather data. Eur J Plant Pathol. 1996;102:9-20. doi: 10.1007/BF01877111

9. Elliott TF, Stephenson SL. Mushrooms of the Southeast. Timber Press, Portland, Oregon Piatkowski J, Krzyzewska A. Effect of some physical factors on growth of five fungal species. Eur Acad Res. 2018;2017;5(2):1069-1078.

10. Gilbertson RL, Ryvarden L. North American polypores. Abortiporus-Lindtneria. Fungiflora A/, Oslo, Norway. 1986;1.

11. Gilbertson RL, Ryvarden L. North American Polypores Vol. 2. Megasporoporia-Wrightoporia Fungiflora A/, Oslo, Norway. 1987.

12. Griffin DM. Water potential and wood-decay fungi. Annual Review of Phytopathology. 1977;15(1):319329. doi: 10.1146/annurev.py.15.090177.001535

13. Hall TA. BIOEDIT V7.0.9: A user-friendly biological sequence alignment editor and analysis program for windows 95/98/NT Nucl Acids Symp Ser. 2006;41(1999):95-98.

14. Jacobson K, Diepeningen AV, Evans S, et al. Non-Rainfall Moisture Activates Fungal Decomposition of Surface Litter in the Namib Sand Sea. PLoS One. 2015;10(5):122. doi: 10.1371/journal.pone.0126977

15. Jeffries DL. Vegetation Analysis of Sandstone Glades in Devil's Den State Park, Arkansas. Castanea. 1987;52(1):9-15.

16. Kazemian N, Pakpour S, Milani AS. Klironomos J. Environmental factors influencing fungal 
growth on gypsum boards and their structural biodeterioration: A university campus case study. PLOS One. 2019;14(8):e0220556. doi: 10.1371/journal. pone. 0220556

17. Leiniger TD, Wilson AD, Lester DG. Hurricane Andrew damage in relation to wood decay fungi and insects in bottomland hardwoods of the Atchafalaya Basin, Louisiana. J Coast Res. 1997;13:1290-1293.

18. Ligne LD, de Ulzurrun GVD, Baetens JM, den Bulcke JV, Acker JV, Baets BD. Analysis of spatio-temporal fungal growth dynamics under different environmental conditions. IMA Fungus. 2019;10(7):1-13. doi: 10.1186/s43008-019-0009-3

19. Lonsdale D, Pautasso M, Holdenrieder O. Wooddecaying fungi in the forest: conservation needs and management options. European Journal of Forest Research. 2008;127:1-22. doi: 10.1007/s10342-0070182-6

20. Miller Jr OK, Miller HH. Mushrooms of North America in color: A field guide companion to seldom-illustrated fungi. Syracuse University Press, New York. 1995.
21. Odling-Smee FJ, Laland KN, Feldman MW. Niche construction - the neglected process in evolution. Princeton University Press, Princeton. 2003.

22. Simila $\mathrm{M}$, Kouki J, Monkkonen $\mathrm{M}$, Sippola AL, Huhta E. Covariation and indicators of species diversity: can richness of forest-dwelling species be predicted in northern boreal forests? Ecol Indic. 2006;6(4):686-700. doi: 10.1016/j.ecolind.2005.08.028

23. Sotome K, Akagi Y, Lee SS, Ishikawa NK, Hattori T. Taxonomic study of Favolus and Neofavolus gen. nov. segregated from Polyporus (Basidiomycota, Polyporales). Fungal Diversity. 2013;58:245-266. doi: 10.1007/s13225-012-0213-6

24. Vacher S, Hernandez C, Bartschi C, Poussereau N. Impact of paint and wall-paper on mould growth on plasterboards and aluminum. Building and Environment. 2010;45(4):916-921. doi: 10.1016/j. buildenv.2009.09.011

25. White TJ, Madej R, Persing DH. The polymerase chain reaction: clinical applications. In Advances in Clinical Chemistry, Elsevier, USA. 1992;29:161-196. doi: 10.1016/S0065-2423(08)60224-3 